\title{
REVIEW
}

\section{Bone Tissue as a Systemic Endocrine Regulator}

\section{ZOFKOVA ${ }^{1}$}

${ }^{1}$ Institute of Endocrinology, Prague, Czech Republic

Received August 26, 2014

Accepted October 24, 2014

On-line December 3, 2014

\section{Summary}

Bone is a target tissue for hormones, such as the sex steroids, parathormon, vitamin D, calcitonin, glucocorticoids, and thyroid hormones. In the last decade, other "non-classic" hormones that modulate the bone tissue have been identified. While incretins (GIP and GLP-1) inhibit bone remodeling, angiotensin acts to promote remodeling. Bone morphogenetic protein (BMP) has also been found to have anabolic effects on the skeleton by activating bone formation during embryonic development, as well as in the postnatal period of life. Bone has also been identified as an endocrine tissue that produces a number of hormones, that bind to and modulate extra-skeletal receptors. Osteocalcin occupies a central position in this context. It can increase insulin secretion, insulin sensitivity and regulate metabolism of fatty acids. Moreover, osteocalcin also influences phosphate metabolism via osteocyte-derived FGF23 (which targets the kidneys and parathyroid glands to control phosphate reabsorption and metabolism of vitamin D). Finally, osteocalcin stimulates testosterone synthesis in Leydig cells and thus may play some role in male fertility. Further studies are necessary to confirm clinically important roles for skeletal tissue in systemic regulations.

\section{Key words}

Bone morphogenetic peptide - Angiotensin - Incretins • Osteocalcin • Phosphatonins - Phosphate homeostasis • FGF23 • Chronic kidney diseases - Klotho-a • Testosterone • Male reproduction

\section{Corresponding author}

I. Zofkova, Institute of Endocrinology, Narodni 8, 11694 Prague 1, Czech Republic. E-mail: izofkova@upcmail.cz

\section{Introduction}

Bone was originally understood to be a static organ performing mechanical functions while also being the target for sex steroids, calcitonin, $1,25(\mathrm{OH})_{2}$ D vitamin $\left(1,25(\mathrm{OH})_{2} \mathrm{D}_{3}\right)$, glucocorticoids, and thyroid hormones. In the last decade thyrotropin stimulating hormone (TSH) has been shown to activate osteoblast differentiation and inhibit bone resorption independently of $1,25(\mathrm{OH})_{2} \mathrm{D}_{3}$ (Dumic-Cule et al. 2014). TSH administration in small doses, which does not increase serum triiodothyronine or thyroxine levels, prevents progressive bone loss in OVX rats (Sampath et al. 2007). In a clinical study, a negative correlation between serum TSH and bone resorption markers was found in a group of euthyroid postmenopausal women (Zofkova and Hill 2008). Recently other hormones, such as incretins (Yamada 2012), growth factors (Chen et al. 2004) and angiotensin (Asaba et al. 2009) have been shown to regulate the skeleton directly.

Additionally, bone has been identified as an endocrine tissue that produces hormones that modulate extra-skeletal systems, such as energy metabolism, phosphate homeostasis and/or male fertility. This review focuses on some of the non-classic relationships that exist between bone and systemic hormones and/or metabolic parameters.

\section{Regulation of bone metabolism by incretins}

The fundamental function of incretins, such as gastric inhibitory polypeptides (GIP) and glucagon-like peptide-1 (GLP-1) is stimulation of insulin secretion in pancreatic beta-cells after meals. GIP receptors are also expressed on osteoblasts and GLP-1 receptors can be 
found on thyroid C-cells. While GIP stimulates osteoblasts and increases bone formation, GLP-1, via Ccells, inhibits bone resorption (Yamada 2012). Increases in serum GIP after meals could explain acute postprandial changes in bone remodeling (Yavropoulou and Yovos 2013). A decline in GIP and/or GLP-1 leads to a decline in bone metabolism, which could be one of the mechanisms inducing osteopenia in diabetics (Yamada 2012). Novel incretin-based pharmaceuticals, e.g. GLP-1 receptor agonists, which have been introduced for treatment of type 2 diabetes, also have bone protective effects, the efficiency of which is being investigated (Dicembrini et al. 2012).

Influence of bone morphogenetic peptide (BMP) on bone metabolism

Hormones modulating bone metabolism are also BMPs. These multifunctional growth factors are members of the transforming growth factor beta (TGF- $\beta$ ) superfamily. They regulate embryonic development of the skeleton, as well as postnatal bone formation. BMP signaling in bone is mediated by type I and type II receptors, which stimulate downstream molecules such as Smad1, Smad5 and Smad8. After phosphorylation, these molecules form the Smad4 complex, which is translocated into the nucleus of osteoblast. Once in the nucleus it interacts with the Runx2 molecule and activates bone formation. BMP signaling is inhibited by the protein Noggin. Over-expression of noggin in osteoblasts leads to osteoporosis in mice (Chen et al. 2004). Another molecule, which inhibits BMP signaling, via negative interaction with Smad, is the Tob factor, which interacts specifically with BMP activated Smad proteins and inhibits BMP signaling. In Tob null mutant mice, BMD signaling is activated and bone formation is enhanced (Chen et al. 2004). Another transcription factor that recognizes bone-specific Runx2 and induces its degradation is Smurf1. Smurf1 interacts with Smad1 and Smad5 and mediates their degradation. Over-expression of Smurf1 in osteoblasts inhibits postnatal bone formation in mice (Chen et al. 2004).

BMP also has osteoanabolic effects on the adult skeleton. It potentiates muscle growth and inhibits muscle wasting. Thus, direct anabolic effects of BMP on the skeleton are further potentiated by an increase in muscle mass volume (Winkbands et al. 2013). The influence of BMP on fracture healing is also being investigated (Collinge 2013).

Finally, new pharmaceuticals that activate Runx or Smad molecules or inhibit Noggin or Tob, in ways similar to recombinant incretins, are promising molecules for the treatment of osteoporosis.

\section{The role of angiotensin in modulation of bone remodeling}

Besides incretins and BMP, bone is the target for angiotensin II, which markedly stimulates bone-turnover. Although the primary locus of angiotensin action are osteoblasts, activation of bone formation is followed by exaggerated production of RANKL (receptor activator of NF-kappa B ligand), which stimulates osteoclastogenesis. Enhanced activity of the renin-angiotensin system accelerates bone resorption (in similar ways as inflammatory cytokines IL-1 and TNF-alpha), which induces 'high-turnover osteoporosis' in mice, mostly independent of hypertension development (Asaba et al. 2009). Research in humans has shown that treatment of hypertension with angiotensin-converting enzyme (ACE) inhibitors (e.g. enalapril) can reduce the risk of fractures. Therefore, negative modulators of renin-angiotensin system could be considered potential pharmaceuticals for treatment of osteoporosis in patients with hypertension (Nakagami et al. 2012). Further studies evaluating the protective effects of ACE inhibitors on human skeleton are needed.

\section{Endocrine and metabolic functions of bone}

Our view of the skeleton has been enriched by new information that defines bone as an endocrine tissue that modulates other body systems. From this point of view, the most important hormone synthetized by osteoblasts and osteocytes is osteocalcin, activated by $\gamma$ carboxylation process.

Involvement of osteoblastic cell line (osteocytes) in regulation of bone metabolism

Remodeling and modeling of the skeleton comes from interactions between the activities of osteoblastic cell line and osteoclasts. While osteoclasts are derived from the monocyte-macrophage linage, osteoblast cell line is of a mesenchymal origin. These cells will express RANKL, which, together with a number of cytokines, activate osteoclastogenesis. Moreover, osteocytes also synthesize osteoprotegerin (a decoy receptor for RANKL), which inhibits interaction between RANKL and RANK and thus inhibits osteoclastogenesis (Kitamura et al. 2013, Takahashi et al. 2011). Maturation of bone forming osteoblastic cell line is promoted by the 
canonical pathway of Wnt (wingless proteins), as well as by hormones produced in osteocytes $1,25(\mathrm{OH})_{2} \mathrm{D}_{3}$ (Turner et al. 2014) and BMP-4 (activated by the p38 MAP kinase) (Kondo et al. 2014). As a result mutual relationships between the parameters of RANK-RANKLOPG axis determine an equilibrium between bone resorption and bone formation.

In bone the osteoblast-derived osteocyte occupies the role of endocrine cell, which synthesizes $1,25(\mathrm{OH})_{2} \mathrm{D}_{3}$, fibroblasts growth factor (FGF23) (see below), and osteocalcin. Osteocalcin, via G-protein receptors GPRC6A, stimulates some of the extra-skeletal systems, such as pancreatic beta cells and testicular Leydig cells. Furthermore, the hormone modulates metabolism of fatty acids and potentiates male fertility (Pi and Quarles 2013, Oury et al. 2011, Karsenty and Oury 2014). FGF23 has been found a major phosphate regulatory hormone, similarly as parathyroid hormone or $1,25(\mathrm{OH})_{2} \mathrm{D}_{3}$ (Doyle and Jan de Beur 2008).

\section{Role of osteoblastic cell line in energy homeostasis}

There are mutual interactions between bone and energy metabolism in vertebrates (Raska et al. 2009). Osteocalcin (which is under the negative control of the Esp gene) activates insulin synthesis in beta cells and increases insulin sensitivity in fat, liver and muscles (Hinoi 2012). Osteocalcin deficient mice developed hyperglycemia, insulin resistence, and high body adiposity (Wolf 2008). In healthy women, serum osteocalcin has been shown to be inversely related to parameters of glucose metabolism, such as glycemia or hemoglobin A1c (HbA1c) levels (Weiler et al. 2013). In schoolchildren, an inverse correlation between the total and/or under-carboxylated osteocalcin levels and adiposity has been observed (Boucher-Berry et al. 2012). Thus Boucher-Berry postulated that the markers of bone metabolism might also reflect the risk for adiposity in children. On the other hand, adipocyte-derived leptin, via the central sympathetic nervous system, inhibits osteoblast activity and osteocalcin synthesis and slows down bone formation (Hinoi 2012).

On the basis of feedback loop the direct interaction between insulin and bone is also working. The insulin signaling pathway positively influences osteoblast proliferation, differentiation and survival and modulates bone growth. An impairment of insulin signaling pathway in bone leads to an impaired bone quality in mice, together with obesity and insulin resistance (Pramojanee et al. 2014). Furthermore, poor metabolic control is associated with reduced bone formation in children and adolescents (Wedrychowicz et al. 2014). Finally, the bidirectional cross-talk between energy metabolism and skeletal tissue plays a role in energy balance regulation and vice versa.

\section{Osteoblastic cell line influences phosphate homeostasis}

Adequate phosphate levels are necessary for development of the skeleton in childhood and maintenance of its integrity in adulthood. Until recently, vitamin D and PTH have been thought to regulate phosphate metabolism at the level of the kidneys, intestines and bone. The precursor molecule $25(\mathrm{OH}) \mathrm{D}_{3}$ is metabolized into an active form $\left(1,25(\mathrm{OH})_{2} \mathrm{D}_{3}\right)$ not only in the liver and kidneys, but also in a number of bone cells, including osteoblasts (Qaw et al. 1992). Furthermore, $1,25(\mathrm{OH})_{2} \mathrm{D}_{3}$ can activate osteoblasts directly by increasing production of ALP and osteocalcin, which stimulates formation and mineralization of the skeleton. In other words, osteoblast could be defined as target for $1,25(\mathrm{OH})_{2} \mathrm{D}_{3}$, as well as an endocrine cell synthesizing $1,25(\mathrm{OH})_{2} \mathrm{D}_{3}$ (Anderson et al. 2012, van Driel et al. 2006).

In addition to the well- known PTH - vitamin D axis, phosphatonins, such as FGF23, sFRP-4 and MEPE, may play some role in long-term regulation of phosphate homeostasis. Most investigated phosphatonin FGF23 is synthesized by osteocytes (Lee et al. 2014). FGF23, via GPRC6A receptor targets a limited number of tissues, such as the kidneys and parathyroid glands, choroid plexus, and pituitary gland that coexpress FGF receptors and $\alpha$-Klotho complexes. FGF23 via GPRC6A controls phosphate reabsorption and metabolism of vitamin $\mathrm{D}$ (Neve and Cantatore 2012). Gene transcription of FGF23 is positively regulated by $1,25(\mathrm{OH})_{2} \mathrm{D}_{3}$ and serum phosphate and negatively regulated by PHEX (phosphate regulating gene located on the $X$ chromosome) (Cavalli et al. 2012).

An elementary co-receptor for phosphatonins (including FGF23) is the transmembrane protein, Klotho. This peptide (251 amino acids) acts as a cofactor that is essential for the interaction between FGF23 and its receptor (Kurosu and Kuro-o 2009). Klotho is expressed (under control of aging suppressor gene) in the parathyroid glands and kidneys, and regulates PTH, vitamin $\mathrm{D}$ synthesis and phosphate excretion (Torres et al. 2009, John et al. 2011, Kuro-o 2012). In Klothodeficient mice, calcinosis of vessels accelerates, probably involving the Runx factor and hypervitaminosis D, and induces premature aging (Lim et al. 2012). Klotho 
declines with age and during certain phase of some chronic diseases (Kuro-o 2012).

IGF23 functions as a phosphaturic factor (Kuro-o 2012). While mutations in the FGF23 or Klotho genes lead to hypervitaminosis D, hyperphosphatemia, hyperostosis, and ectopic calcifications, high activity of FGF23 inhibits synthesis of $1,25(\mathrm{OH})_{2} \mathrm{D}_{3}$ (via activation of Cyp24) and induces hereditary and acquired hypophosphatemic rickets (Cavalli et al. 2012, Quarles 2012).

Levels of FGF23 increase in patients with chronic kidney disease (CKD) (Kuro-o 2012). In the initial phase of CKD, increased production of FGF23 functions as an adaptive mechanism, which reduces exaggerated phosphate absorption in the intestines, inhibits $1,25(\mathrm{OH})_{2} \mathrm{D}_{3} \quad$ synthesis, and brakes overproduction of PTH. Thus, FGF23-Klotho system protects organisms against retention of phosphate, a vascular toxin that accelerates arterial stiffness and coronary calcification (Shroff 2013). In the advanced stages of CKD, further increases in PTH levels amplify the synthesis of FGF23 as compensation for increased phosphate efflux from bone tissue, which is caused by excessive bone resorption (Quarles 2012). However, Klotho expression in the kidneys and parathyroids is seen to decline during this phase of CKD (Kuro-o 2012). Under this condition, progressive increases in FGF23 lead to secondary hyperparathyroidism, which further amplifies FGF23 expression and together with low Klotho and hyperphosphatemia quickens vascular calcification and increases the risk of cardiovascular mortality (Quarles 2012). In vivo, Klotho deficiency can be restored with vitamin $\mathrm{D}$ receptor activators, which renew the anticalcific ability of the FGF23-Klotho system (Lim et al. 2012).

Osteocyte derived FGF23, after modulation by Klotho, regulates urinary phosphate excretion, $\mathrm{PTH}$, and $1,25(\mathrm{OH})_{2} \mathrm{D}_{3}$ synthesis and in this way is involved in the progress of $\mathrm{CKD}$ and vascular damage.

\section{Does bone regulate male reproduction?}

Until now, the relationship between the skeleton and reproduction has been considered limited to the regulation of bone remodeling via sex steroids. It is well known, that androgens and estrogens are responsible for sexual dimorphism in development of peak bone mass and adaptation of bone to mechanical loading (Laurent $e t$ al. 2014). Androgen insufficiency, due to an imbalance in the hypophyseal-gonadal axis together with other factors, such as low activity of enzymes regulating sex steroid production, disorders in thyroid function, oxidative stress, genetic factors, autoimmunity together with life style and nutritional factors (e.g. zinc deficiency), can lead to male infertility (Kumar et al. 2014).

Recently it has been shown that male fertility is also under control of skeletal tissue. Steroidogenic enzymes cytochromes P450scc and P450c17, required for synthesis and release of testosterone can be induced by osteocalcin through the GPRC6A receptor that is localized on Leydig cells (Karsenty and Oury 2014, Oury et al. 2011, Okuyama et al. 2014). Therefore, osteocalcin deficiency could be hypothetically considered as a new pathogenetic factor responsible for primary testicular failure in men. This hypothesis remains to be confirmed through clinical studies.

\section{Concluding remarks}

A modern understanding of skeletal tissue must now include previously unrecognized roles in the physiology and pathophysiology of organisms. The skeleton more than just a target tissue hormones, it is also an important endocrine structure as well. Understanding the bi-directional interaction between bone tissue and circulating hormones is an enormous challenge from a practical point of view. Synthetic molecules of incretins, used in the treatment of type 2 diabetes may offer new perspectives for the treatment of osteoporosis. This may also be true of molecules that activate Runx or Smad, or inhibit Noggin or Tob in the BMP signaling pathway. Furthermore, negative modulators of the reninangiotensin system can be considered potential pharmaceuticals for effective treatment of both hypertension and osteoporosis.

We have also seen that the bone-derived hormone osteocalcin positively modulates expression of extra-skeletal hormones, such as insulin in pancreatic beta cells and testosterone in Leydig cells. From this point of view, osteocalcin could be viewed as perspective hormone for the treatment of metabolic syndrome in type 2 diabetes, as well as male infertility.

Phosphatonins, produced by skeletal tissue, could have CKD diagnostic value. Serum FGF23 levels fluctuate relative to the phase of $\mathrm{CKD}$. In the late phase, large increase in FGF23 levels fails to protect against toxic phosphate retention and enhances vascular calcification. Thus, serum FGF23 might represent a promising putative marker of cardiovascular risk in CKD patients.

Finally, bone appears to be an important 
endocrine link in the overall regulation of homeostasis. New information regarding interactions between bone and extra-skeletal systems may suggest new treatments for many conditions, not just osteoporosis.

\section{Conflict of Interest}

There is no conflict of interest.

\section{Acknowledgements}

This work was supported by the project (Ministry of Health, Czech Republic) for conceptual development of research organization 00023761 (Institute of Endocrinology, Prague, Czech Republic).

\section{References}

ANDERSON PH, ATKINS GJ, TURNER AG, KOGAWA M, FINDLAY DM, MORRIS HA: Vitamin D metabolism within bone cells: effects on bone structure and strength. Moll Cell Endocrinol 347: 42-47, 2011.

ANDERSON PH, TURNER AG, MORRIS HA: Vitamin D actions to regulate calcium and skeletal homeostasis. Clin Biochem 45: 880-886, 2012.

ASABA Y, ITO M, FUMOTO T, WATANABE K, FUKUHARA R, TAKESHITA S, NIMRA Y, ISHIDA J, FUKAMIZU A, IKEDA K: Activation of renin-angiotensin system induces osteoporosis independenty of hypertension. J Bone Miner Res 24: 241-250, 2009.

BOUCHER-BERRY C, SPEISER PW, CAREY DE, SHELOV SP, ACCACHA S, FENNOY I, RAPAPORT R, ESPINAL Y, ROSENBAUM M: Vitamin D, osteocalcin, and risk for adiposity as comorbidities in middle school children. J Bone Miner Res 27: 283-293, 2012.

CAVALLI L, MAZZOTTA C, BRANDI ML: Phosphatonins: physiological role and pathological changes. Clin Cases Miner Bone Metab 9: 9-12, 2012.

CHEN D, ZHAO M, MUNDY GR: Bone morphogenetic proteins. Growth Factors 22: 233-241, 2004.

COLLINGE C: An injectable BMP cocktail for fracture-healing - a study that others have only imagined: commentary on an article by Thomas Lyon, MD, et al.: "Efficasy and safety of recombinant human bone morphogenetic protein-2/calcium phosphate matrix for closed tibial diaphyseal fracture. A double-blind, randomized, controlled phase-II/III trial“. J Bone Joint Surg Am 95: e1891-e1892, 2013.

DICEMBRINI I, MANNUCCI E, ROTELLA CM: Bone: Incretin hormones perceiver or receiver? Exp Diabetes Res 2012: ID 519784, 2012.

DOYLE ME, JAN DE BEUR SM: The skeleton: endocrine regulator of phosphate homeostasis. Curr Osteoporos Rep 6: 134-141, 2008.

DUMIC-CULE I, DRACA N, LUETIC AT, JEZEK D, ROGIC D, GRGUREVIC L, VOKICEVIC S: TSH prevents bone resorption and with calcitriol synergistically stimulates bone formation in rats with low levels of calciotropic hormones. Horm Metab Res 46: 305-312, 2014.

HINOI E: Pivotal role of skeletal tissues in the regulation mechanisms for physiological functions mediated by multiple organ networks. Yakugaku Zasshi 132: 721-725, 2012.

JOHN GB, CHENG CY, KURO-O M: Role of Klotho in aging, phosphate metabolism, and CKD. Am J Kidney Dis 58: 127-134, 2011.

KARSENTY G, OURY F: Regulation of male fertility by the bone-derived hormone osteocalcin. Mol Cell Endocrinol 382: 521-526, 2014.

KITAMURA K, TAKAHIRA K, INARI M, SATOH Y, HAYAKAWA K, TABUCHI Y, OGAI K, NISHIUCHI T, KONDO T, MIKUNI-TAKAGAKI Y, CHEN W, HATTORI A, SUZUKI N: Zebrafish scales respond differently to in vitro dynamic and static acceleration: analysis of interaction between osteoblasts and osteoclasts. Comp Biochem Physiol A Mol Integr Physiol 166: 74-80, 2013.

KONDO A, TOKUDA H, MATSUSHIMA-NISHIWAKI R, KUROYANAGI G, YAMAMOTO N, MIZUTANI J, KOZAWA O, OTSUKA T: Rho-kinase limits BMP-4-stimulated osteocalcin synthesis in osteoblasts: regulation of the p38 MAP kinase pathway. Life Sci 96: 18-25, 2014.

KUMAR A, SHEKHAR S, DHOLE B: Thyroid and male reproduction. Indian J Endocrinol Metab 18: 23-31, 2014.

KURO-O M: Klotho and $\beta$ Klotho. Adv Exp Med Biol 728: 25-40, 2012. 
KUROSU H, KURO-O M: The Klohto gene family as a regulator of endocrine fibroblast growth factors. Moll Cell Endocrinol 299: 72-78, 2009.

LAURENT M, ANTONIO L, SINNESAEL M, DUBIOS V, GIELEN E, CLASSENS F, VANDERSCHUEREN D: Androgens and estrogens in skeletal sexual dimorphism. Asian J Androl 16: 213-222, 2014.

LEE JW, YAMAGUCHI A, LIMURA T: Functional heterogeneity of osteocytes in FGF23 production: the possible involvement of DMP1 as a direct negative regulator. Bonekey Rep 3: Art. Nr. 543, 2014.

LIM K, LU TS, MOLOSTVOV G, LEE C, LAM FT, ZEHNDER D, HSIAO LL: Vascular Klotho deficiency potentiates the development of human artery calcification and mediates resistance to fibroblast growth factor 23. Circulation 125: 2243-2255, 2012.

NAKAGAMI H, OSAKO MK, MORISHITA R: Potential effect of angiotensin II receptor blockade in adipose tissue and bone. Curr Pharm Des 19: 3049-3053, 2013.

NEVE A, CORRADO A, CANTATORE FP: Osteocytes: central conductors of bone biology in normal and pathological conditions. Acta Physiol (Oxf) 204: 317-330, 2012.

OKUYAMA MW, SHIMOZURU M, YANAGAWA Y, TSUBOTA T: Changes in the immunolocalization of steroidogenic enzymes and the androgen receptor in raccoon (Procyon lotor) testes in association with the seasons and spermatogenesis. J Reprod Dev 60: 155-161, 2014.

OURY F: A crosstalk between bone and gonads. Ann N Y Acad Sci 1260: 1-7, 2012.

OURY F, SUMARA G, SUMARA O, FERRON M, CHANG H, SMITH CE, HERMO L, SUAREZ S, ROTH BL, DUCY P, KARSENTY G: Endocrine regulation of male fertility by the skeleton. Cell 144: 796-809, 2011.

PI M, QUARLES LD: Novel bone endocrine networks integrating mineral and energy metabolism. Curr Osteoporos Rep 11: 391-399, 2013.

PRAMOJANEE SN, PHIMPHILAI M, CHATTIPAKORN N, CHATTIPAKORN SC: Possible roles of insulin signaling in osteoblasts. Endocr Res 39: 144-151, 2014.

QAW FS, MAKIN HL, JONES G: Metabolism of 25-hydroxydihydrotachysterol 3 in bone cells in vitro. Steroids 57 : 236-243, 1992.

QUARLES LD: Skeletal secretion of FGF-23 regulates phosphate and vitamin D metabolism. Nat Rev Endocrinol 8: 276-286, 2012.

RASKA O, BERNASKOVA K, RASKA I Jr: Bone metabolism: a note on the significance of mouse models. Physiol Res 58: 459-471, 2009.

SAMPATH TK, SIMIC P, SENDAK R, DRACA N, BOWE AE, O'BRIEN S, SCHIAVI SC, MCPHERSON JM, VUKICEVIC S: Thyroid-stimulating hormone restores bone volume, microarchitecture, and strength in aged ovariectomized rats. J Bone Miner Res 22: 849-859, 2007.

SHROFF R: Phosphate is a vascular toxin. Pediatr Nephrol 28: 583-93, 2013.

TAKAHASHI N, MAEDA K, ISHIHARA A, UEHARA S, KOBAYASHI Y: Regulatory mechanism of osteoclastogenesis by RANKL and Wnt signals. Front Biosci (Landmark Ed.) 16: 21-30, 2011.

TORRES PU, PRIÉ D, BECK L, DE BRAUWERE D, LEROY C, FRIEDLANDER G: Klotho gene, phosphocalcic metabolism, and survival in dialysis. J Ren Nutr 19: 50-56, 2009.

TURNER AG, HANRATH MA, MORRIS HA, ATKINS GJ, ANDERSON PH: The local production of $1,25(\mathrm{OH})_{2} \mathrm{D}_{3}$ promotes osteoblast and osteocyte maturation. J Steroid Biochem Mol Biol 144: 114-118, 2014.

VAN DRIEL M, KOEDAM M, BUURMAN CJ, HEWISON M, CHIBA H, UITTERLINDEN AG, POLS HA, VAN LEEUWEN JP: Evidence for auto/paracrine actions of vitamin D in bone: $1 \alpha$-hydroxylase expression and activity in human bone cells. FASEB J 20: 2417-2419, 2006.

WEDRYCHOWICZ A, STEC M, SZTEFKO K, STARZYK JB: Associations between bone, fat tissue and metabolic control in children and adolescents with type 1 diabetes mellitus. Exp Clin Endocrinol Diabetes 122: 491-495, 2014.

WEILER HA, LOWE J, KRAHN J, LESLIE WD: Osteocalcin and vitamin D status are inversely associated with homeostatic model assessment of insulin resistance in Canadian Aboriginal and white women: the First Nations Bone Health Study. J Nutr Biochem 24: 412-418, 2013. 
WINBANKS CE, CHEN JL, QIAN H, LIU Y, BERNARDO BC, BEYER C, WATT KI, THOMSON RE, CONNOR T, TURNER BJ, MCMULLEN JR, LARSSON L, MCGEE SL, HARRISON CA, GREGOREVIC P: The bone morphogenetic protein axis is a positive regulator of skeletal muscle mass. J Cell Biol 203: 345-357, 2013.

WOLF G: Energy regulation by the skeleton. Nutr Rev 66: 229-233, 2008.

YAMADA Y: Diabetes mellitus and osteoporosis. Incretin as a coordinator of glucose and bone metabolism. Clin Calcium 22: 1353-1358, 2012.

YAVROPOULOU MP, YOVOS JG: Incretins and bone: evolving concepts in nutrient-dependent regulation of bone turnover. Hormones (Athens) 12: 214-223, 2013.

ZOFKOVA I, HILL M: Biochemical markers of bone remodeling correlate negatively with circulating TSH in postmenopausal women. Endocr Regul 42: 121-127, 2008. 